\title{
Potensi Anti-inflamasi Fraksi Etil Asetat Ranting Patah Tulang (Euphorbia tirucalli L.) dengan Uji Penghambatan Denaturasi Protein
}

\section{Anti-inflammation Potential of Ethyl Acetate Fraction of Milk Bush (Euphorbia tirucalli L.) by Protein Denaturation Inhibition Test}

\author{
Zainal Abidin*, Uni Angreni Putri, Harti Widiastuti \\ Fakultas Farmasi, Universitas Muslim Indonesia \\ Jl. Urip Sumoharjo Km 5 Kampus 2 UMI \\ Kontak*: zainal.abidin@umi.ac.id
}

\begin{abstract}
ABSTRAK
Ranting Patah tulang (Euphorbia tirucalli L.) mengandung senyawa flavonoid berpotensi sebagai antiinflamasi. Penelitian ini bertujuan untuk menentukan potensi anti-inflamasi fraksi etil asetat patah tulang dengan menggunakan uji penghambatan denaturasi protein. Penelitian ini terdiri dari tiga kelompok percobaan yang terdiri dari kontrol negatif, kontrol positif natrium diklofenak, dan fraksi etil asetat patah tulang sebagai kelompok uji. Potensi anti-inflamasi $\left(\mathrm{IC}_{50}\right)$ natrium diklofenak memiliki nilai sebesar $26,46 \mu \mathrm{g} / \mathrm{ml}$. Sedangkan fraksi etil asetat ranting patah tulang memiliki nilai $\mathrm{IC}_{50}$ sebesar $250,53 \mu \mathrm{g} / \mathrm{ml}$. Hasil tersebut menunjukan bahwa ranting patah tulang berpotensi sebagai anti-inflamasi.
\end{abstract}

Kata Kunci: Denaturasi Protein, Inflamasi, Ranting Patah Tulang (Euphorbia tirucalli L.).

\begin{abstract}
The Milk bush (Euphorbia tirucalli L.) that contains flavonoids is potential to be anti-inflammation. The aim of this research was to determine the anti-inflammation potential of ethyl acetate fraction of milk bush by protein denaturation inhibition test. The research was implemented in three experimental groups, such as; negative control, sodium diclofenac as positive control, and ethyl acetate fraction of milk bush as test group. The potential of antiinflammation $\left(I_{50}\right)$ of sodium diclofenac has $26.46 \mu \mathrm{g} / \mathrm{ml}$ of $I_{50}$. Meanwhile, $I C_{50}$ of ethyl acetate fraction of milk bush has 250,53 $\mathrm{g} / \mathrm{ml}$. This result showed that the milk bush has the potential to be anti-inflammation.
\end{abstract}

Keywords: Protein denaturation, inflammation, Milk Bush (Euphorbia tirucalli L.).

\section{PENDAHULUAN}

Pemanfaatan tanaman sebagai obat tradisional bukanlah hal yang baru, dan telah dikenal masyarakat secara luas sejak zaman dahulu. Dewasa ini penggunaan obat-obatan yang berasal dari tanaman, banyak diminati oleh kalangan masyarakat, meskipun telah banyak beredar obat jadi yang merupakan senyawa sintesis. Hal ini dibuktikan dengan adanya kecenderungan masyarakat global untuk kembali ke alam (back to nature) dalam bidang penyediaan obat-obatan (Mahatma, 2005).

Tanaman patah tulang berasal dari Afrika, namun secara luas ditanam dan mengalami penyebaran di seluruh daerah tropis dan subtropis. Tanaman ini di Indonesia tumbuh dengan baik dan dikenal sebagai salah satu jenis tanaman yang biasa digunakan masyarakat sebagai obat tradisional (Supriyanto, 2010). Tanaman patah tulang juga dapat digunakan sebagai antikanker, 
antitumor, anti-inflamasi, penyakit kulit, dan pengobatan penyakit sifilis. Salah satu kandungan kimia dari tanaman ini adalah flavonoid yang oleh berbagai penelitian terbukti memiliki khasiat sebagai antiinflamasi, dan getah patah tulang berkhasiat sebagai obat luka baru. Sementara itu, daun dan batangnya digunakan untuk mengobati sakit tulang dan persendian (Agral, 2013).

Inflamasi merupakan suatu respon protektif normal terhadap luka jaringan yang disebabkan oleh trauma fisik, zat kimia yang merusak, atau zat-zat mikrobiologik (Mycek, 2001). Kriteria inflamasi adalah ada gejala lokal dan sistemik antara lain berupa migrasi leukosit ke jaringan yang mengalami peradangan (Wilmana, 2007). Anti-inflamasi adalah golongan obat-obat yang memiliki aktivitas menekan atau mengurangi peradangan.

Pada penelitian ini, uji anti-inflamasi dilakukan dengan metode penghambatan denaturasi protein secara spektrofotometri UV-Vis merupakan uji skrining awal aktivitas inflamasi. Denaturasi protein merupakan sebuah proses dimana protein kehilangan struktur tersier dan struktur sekundernya oleh senyawa eksternal, seperti asam kuat, basa kuat, garam organik terkonsentrasi, organik pelarut, dan pemanasan. Denaturasi protein dapat menjadi penyebab inflamasi. Senyawa yang dapat menghambat denaturasi protein digunakan sebagai obat anti-inflamasi. Beberapa obat anti-inflamasi menunjukkan kemampuan menghambat denaturasi protein yang disebabkan oleh suhu (Aditya, 2015). Selain itu, pengujian secara in vitro pengaruh pemanasan terhadap anti-denaturasi Bovine Serum Albumin, dapat digunakan untuk mendeteksi adanya senyawa anti-inflamasi (Tatti, Anitha, Shashidhara, Deepak, \& Bidari, 2012). Hal ini dikarenakan metode pengujian denaturasi protein merupakan metode yang layak dan sederhana untuk menilai potensial obat anti-inflamasi (Alhakmani, Kumar, \& Khan, 2013)

Umumnya pengobatan yang digunakan untuk mengatasi terjadinya anti-inflamasi adalah obat modern dari golongan Anti Inflamasi Non Steroid (AINS) dan golongan steroid yang berguna untuk mengurangi pembengkakan dan rasa sakit peradangan (Madvani, 2012). Namun efek samping yang dapat ditimbulkan oleh obat-obatan modern khususnya obat-obat golongan non steroid adalah kerusakan gastrointestinal (dispesia, mual, dan gastritis). Efek samping yang paling serius adalah pendarahan gastrointestinal (Neal, 2006). Oleh karena efek samping dari penggunaan obat tersebut maka perlu dilakukan penelitian pada fraksi etil asetat ranting patah tulang sebagai antiinflamasi, guna mendapatkan sumber obat anti-inflamasi yang lebih aman.

\section{METODE PENELITIAN}

\section{Bahan dan alat}

Bahan-bahan yang digunakan dalam penelitian ini antara lain ranting patah tulang yang diperoleh dari Kota Pare-pare, asam 
asetat glasial, Bovine Serum Albumin, natrium klorida, natrium diklofenak, dan Tris base (Merck), dan fraksi ranting patah tulang (Euphorbia tirucalli L.). Alat yang digunakan adalah Spektrofotometer UV-Vis Apel PD303UV.

\section{Penyiapan Sampel dan Ekstraksi Sampel}

Sampel yang digunakan dalam penelitian ini adalah tanaman ranting patah tulang (gambar 1). Sampel dikeringkan dengan cara diangin-anginkan. Sampel yang telah kering disortasi kering kemudian dihaluskan dengan blender. Serbuk simplisia disimpan dalam wadah tertutup rapat dan terhindar dari cahaya matahari. Simplisia sebanyak $50 \mathrm{~g}$ selanjutnya diekstraksi dengan metode maserasi menggunakan penyari etanol, dengan cara perendaman dan pergantian cairan penyari tiap 24 jam. Proses ekstraksi ini dilakukan sebanyak 3 kali replikasi untuk mendapatkan rendemen ekstrak yang tinggi. Hasil ekstraksi ini kemudian dikeringkan hingga diperoleh ekstrak kering.

\section{Pembuatan Fraksi}

Prosedur fraksinasi menggunakan metode ekstraksi padat cair. Ekstrak kental ditimbang sebanyak $4 \mathrm{~g}$ dan ditambahkan pelarut etil asetat pada suhu kamar. Filtrat dipisahkan dari ampas menggunakan metode enap tuang. Prosedur ini kemudian diulangi hingga penyari etil asetat menjadi jernih. Selanjutnya filtrat disaring dengan menggunakan kertas saring. Lalu filtrat diuapkan hingga diperoleh fraksi kental (gambar 2).

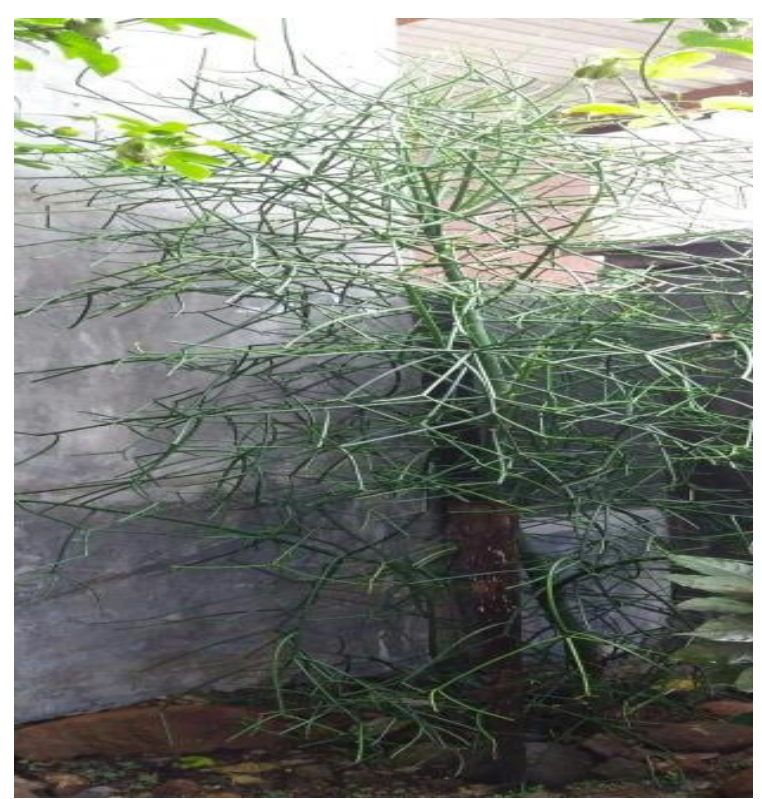

Gambar 1. Tanaman ranting patah tulang

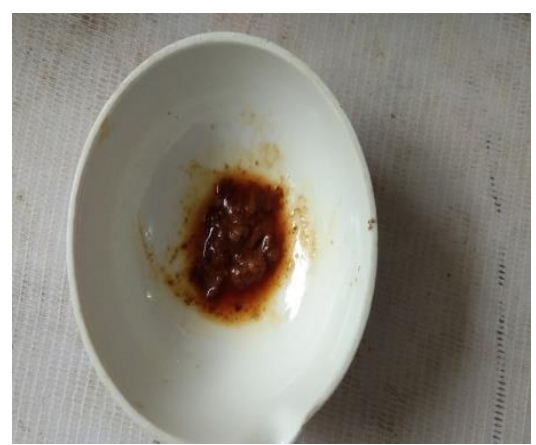

Gambar 2. Fraksi etil asetat ranting patah tulang

\section{Pengukuran Aktivitas Anti-inflamasi}

Metode pengujian berdasarkan prosedur oleh Tatti, Anitha, Shashidhara, Deepak, \& Bidari (2012) dan Alhakmani, Kumar, \& Khan (2013) dengan sedikit modifikasi. Sebanyak $50 \mu \mathrm{L}$ dari setiap konsentrasi larutan sampel (10, 20, 40, 80 dan 160 ppm) dan kontrol positif $(1,2,4,8$, dan $16 \mathrm{ppm})$, ditambahkan larutan Bovine Serum Albumine 0,2 \% dalam pelarut Tris Buffer Saline $\mathrm{pH}$ 6,4, hingga volume mencapai $5 \mathrm{~mL}$. Kemudian larutan diinkubasi pada suhu ruangan selama 30 menit kemudian dipanaskan selama 2 menit pada suhu $100^{\circ} \mathrm{C}$, 
lalu diamkan selama 25 menit pada suhu ruangan. Setelah dingin, larutan divortex dan dilakukan pengukuran absorbansi dengan spektrofotometer UV-Visible pada panjang gelombang $660 \mathrm{~nm}$. Kelompok kontrol menggunakan prosedur yang sama menggunakan air suling sebagai larutan uji (Tatti, Anitha, Shashidhara, Deepak, \& Bidari, 2012; Alhakmani, Kumar, \& Khan, 2013). Aktivitas digambarkan sebagai persen inhibisi menggunakan rumus

$$
\text { Persen Inhibisi }=\frac{A_{S}-A_{C}}{A_{C}} \times 100 \%
$$

dimana $A_{S}=$ Absorbansi sampel dan $A_{C}=$ Absorbansi kontrol negatif

\section{HASIL DAN PEMBAHASAN}

Pengujian aktivitas anti-inflamasi fraksi etil asetat ranting patah tulang menggunakan metode penghambatan denaturasi protein, yang merupakan uji aktivitas anti-inflamasi secara invitro. Fraksinasi bertujuan untuk memisahkan senyawa-senyawa berdasarkan tingkat kepolarannya. Adapun macam-macam metode fraksinasi yaitu ekstraksi cair cair dan ekstraksi padat cair, namun metode yang digunakan pada fraksi etil asetat ranting patah tulang adalah ekstraksi padat cair. Pelarut yang digunakan pada proses ekstraksi padat cair ranting patah tulang adalah etil asetat. Alasan menggunakan pelarut etil asetat sebab dapat melarutkan senyawa-senyawa seperti beberapa alkaloid, flavonoid, monoglikosida, dan glikosida (Syahri, 2016). Ranting patah tulang dipilih karena mengandung senyawa
Tabel 1. Aktivitas anti-inflamasi natrium diklofenak

\begin{tabular}{ccc}
\hline $\begin{array}{c}\text { Konsentrasi } \\
(\mathrm{ppm})\end{array}$ & Absorbansi & $\begin{array}{c}\text { Inhibisi } \\
\%\end{array}$ \\
\hline 1 & 1,469 & 16,817 \\
2 & 1,444 & 18,233 \\
4 & 1,404 & 20,498 \\
8 & 1,303 & 26,217 \\
16 & 1,125 & 36,296 \\
\hline
\end{tabular}

Tabel 2. Aktivitas anti-inflamasi fraksi etil asetat ranting patah tulang

\begin{tabular}{ccc}
\hline $\begin{array}{c}\text { Konsentrasi } \\
(\mathrm{ppm})\end{array}$ & Absorbansi & $\begin{array}{c}\text { Inhibisi } \\
\%\end{array}$ \\
\hline 10 & 1,499 & 15,118 \\
20 & 1,465 & 17,044 \\
40 & 1,412 & 20,045 \\
80 & 1,301 & 26,330 \\
160 & 1,118 & 36,697 \\
\hline
\end{tabular}

flavonoid. Kandungan flavonoid dalam suatu tanaman berpotensi sebagai anti-inflamasi.

Penelitian ini menggunakan tiga kelompok uji yang terdiri dari kontrol negatif, kontrol positif dan larutan sampel terhadap penghambatan denaturasi protein. Pada penelitian uji aktivitas anti-inflamasi pada fraksi etil asetat ranting patah tulang menggunakan Bovine Serum Albumin. Ketika Bovine Serum Albumin dipanaskan maka akan terjadi denaturasi protein, karena suhu merupakan salah satu faktor penyebab terjadinya denaturasi protein. Bovine Serum Albumin dilarutkan dalam Tris Buffer Saline $\mathrm{pH}$ patologis (6,2-6,5). Penggunaan Tris Buffer Saline adalah sebagai larutan penyangga yang berfungsi untuk mempertahankan $\mathrm{pH}$ larutan. Larutan Tris Buffer Saline merupakan larutan penyangga yang dibuat dari campuran larutan Tris dan $\mathrm{NaCl}$. 


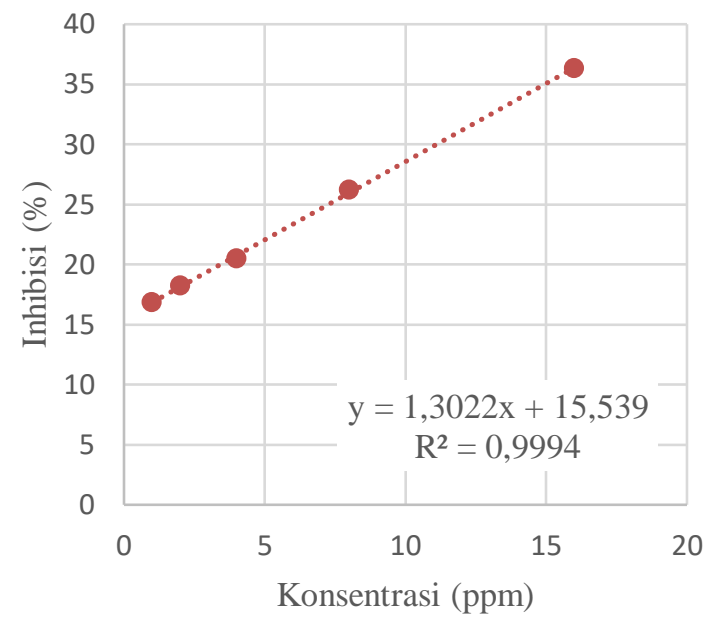

Gambar 3. Kurva inhibisi Natrium Diklofenak

Kontrol negatif menggunakan campuran $50 \mu \mathrm{L}$ pelarut etil asetat dan larutan Bovine Serum Albumin 0,2\% kemudian diinkubasi pada suhu ruangan. Selanjutnya larutan dipanaskan pada suhu $100^{\circ} \mathrm{C}$, divortex dan diukur pada spektrofotometer pada panjang gelombang $660 \mathrm{nmmbar}$, sehingga diperoleh nilai absorbansi dari kontrol negatif yaitu 1,766 .

Kontrol positif yang digunakan adalah natrium diklofenak. Natrium diklofenak dipilih karena merupakan obat anti-inflamasi golongan NSAID yang banyak digunakan untuk mengobati gejala inflamasi serta bahannya mudah didapat. Natrium diklofenak diuji dengan aktivitas inflamasi dengan metode penghambatan denaturasi protein dengan variasi konsentrasi 1, 2, 4, 8, dan 16 ppm. Adapun hasil aktivitas anti-inflamasi natrium diklofenak dapat dilihat pada tabel 1 .

Sedangkan larutan sampel fraksi etil asetat ranting patah tulang menggunakan konsentrasi 10, 20, 40, 80 dan 160 ppm. Ranting patah tulang dipilih karena



Gambar 4. Kurva inhibisi Fraksi Etil Asetat Ranting Patah Tulang

mengandung senyawa flavonoid yang berpotensi sebagai anti-inflamasi (Riansyah, 2015). Adapun hasil aktivitas anti-inflamasi dari fraksi etil asetat ranting patah tulang dapat dilihat pada tabel 2 .

Setelah dilakukan pengujian di atas, selanjutnya dihitung nilai $\mathrm{IC}_{50}$ dari kurva antara konsentrasi (X) dan \% inhibisi (Y). Pada kurva inhibisi natrium diklofenak didapatkan persamaan regresi yaitu $\mathrm{y}=$ $1,302 \mathrm{x}+15,53$ dengan koefisien korelasi $\mathrm{r}=$ 0,999 . Koefisien korelasi yang didapatkan memenuhi syarat, karena koefisien korelasi yang dikatakan baik apabila diperoleh nilai $r$ $\geq 0,998$ (Harmita, 2004), jadi dapat dihitung $\mathrm{IC}_{50}$ dari natrium diklofenak, dan didapatkan hasilnya sebesar 26,463 $\mu \mathrm{g} / \mathrm{ml}$. Pada kurva inhibisi fraksi etil asetat ranting patah tulang didapatkan persamaan regresi yaitu $\mathrm{y}=$ $0,143 \mathrm{x}+14,18$ dengan koefisien korelasi $\mathrm{r}=$ 0,998, yang berarti memenuhi syarat (Harmita, 2004). Nilai IC 50 dari fraksi sampel sebesar $250,534 \mu \mathrm{g} / \mathrm{ml}$. 
Hal ini menunjukkan bahwa semakin besar konsentrasi maka semakin besar pula kemampuan penghambatan denaturasi proteinnya. Dan semakin kecil nilai $\mathrm{IC}_{50}$ berarti aktivitas anti-inflamasinya semakin besar. Dari hasil perhitungan yang didapatkan natrium diklofenak memiliki nilai $\mathrm{IC}_{50}$ sebesar $26,46 \mu \mathrm{g} / \mathrm{mL}$ sedangkan fraksi etil asetat ranting patah tulang memiliki $\mathrm{IC}_{50}$ sebesar $250,53 \mu \mathrm{g} / \mathrm{mL}$.

\section{KESIMPULAN}

Fraksi etil asetat ranting patah tulang memiliki potensi sebagai anti-inflamasi $\left(\mathrm{IC}_{50}\right)$ sebesar $250,53 \mu \mathrm{g} / \mathrm{ml}$.

\section{UCAPAN TERIMA KASIH}

Kami mengucapkan banyak terima kasih kepada Universitas Muslim Indonesia (UMI), terkhusus kepada Fakultas Farmasi dan Laboratorium Kimia Farmasi UMI, yang telah memfasilitasi kebutuhan sarana dan prasarana selama melakukan penelitian ini.

\section{DAFTAR PUSTAKA}

Aditya, M. R. (2015). Potensi Anti-inflamasi Jus Buah Mangga (Garcinia mangostana) Terhadap Denaturasi Protein In Vitro. Jornal Berkala Kedokteran , 149 - 156.

Agral, O. F. (2013). Formulasi dan Uji Kelayakan Sediaan Krim Anti-inflamasi Getah Tanaman Patah Tulang (Euphorbia tirucalli L.). Pharmacon Jurnal Ilimah Farmasi UNSRAT , 1 - 3.

Alhakmani, F.; Kumar, S.; Khan, S. A. (2013). Estimation of total phenolic content, in-vitro antioxidant and antiinflammatory activity of flowers of Moringa oleifera. Asian Pacific of Tropical Biomedicine, 623 - 627.

Harmita. (2004). Petunjuk pelaksanaaan Validasi Metode dan cara perhitungannya. Majalah Kefarmasian Departemen Farmasi FMIPA-UI , 117 - 135.

Madvani, P. M. (2012). Evaluation of AntiInflamatory activity of Citrullus lanatus Seeds Oil by in-Vivo and in-Vitro Models. International Research Journal of Pharmaceutical and Applied Sciences, $104-108$.

Mahatma, A. b. (2005). Pengembangan Bahan Alam dalam industri oabt dan permasalahannya,. Makassar: _.

Mycek, M. J. (2001). Farmakologi Ulasan Bergambar Edisi 2. Jakarta: Widya Medika.

Neal, M. J. (2006). at Glance Farmakologi Medis Edisi 5. Surabaya: Erlangga.

Riansyah, Y. (2015). uji Aktivitas Antiinflamasi Ekstrak Etanol Daun Ubi Talas Ungu (Ipomea batata L) terhadap Tikus Wistar Jantan. Proseding Penelitian SPeSIA (p. 635). Bandung: -.

Supriyanto, S. E. (2010). Pemasaran Industri Jasa Kesehatan. Yogyakarta: Andi Offset.

Syahri, L. (2016). Pengaruh Fraksi Etil Asetat Ekstrak Etanol Buah Kemukus (Piper cubeba L.) Fructus Terhadap Memori Spasial Tikus jantan Galur Wistar Pasca Restraint Stress. Skripsi, Universitas Wahid Hasyim, Fakultas Farmasi, Semarang.

Tatti, P. N.; Anitha, S.; Shashidhara, S.; Deepak, M.; Bidari, S. (2012). Evaluation of In-Vitro Anti-Denaturation Activity of Isolated Compound of Butea monosperma Bark. An International Journal of Pharmaceutical Sciences , 2314 - 2320.

Wilmana, P. F. (2007). Analgetik-Antipiretik, Analgetik-Antiinflamsi Non Steroid dan Obat Pirai. Jakarta: Bagian Farmakologi Fakultas Kedokteran UI. 